\title{
Ecological Footprint Assessment and Reduction of an Academic Building in Shahdol (India)
}

\author{
Dilawar Husain ${ }^{1 *}$, Ravi Prakash ${ }^{1}$ \\ ${ }^{1}$ Motilal Nebru National Institute of Technology Allababad, Teliarganj, 221004 Allahabad, INDIA \\ *Corresponding Author: dilawar4friend@gmail.com \\ Citation: Husain, D. and Prakash, R. (2018). Ecological Footprint Assessment and Reduction of an \\ Academic Building in Shahdol (India). European Journal of Sustainable Development Research, 2(4), 42. \\ https://doi.org/10.20897/ejosdr/3910
}

Published: October 4, 2018

\begin{abstract}
Buildings are responsible for significant natural resource consumption, waste generation, and environmental pollution. Building impacts are generally assessed through life cycle analysis (LCA). This study integrates LCA with the Ecological Footprint indicator for the assessment of a building's impact on the planet. In order to determine ecological impact of a building, a methodology has been established for estimation of Life Cycle Ecological Footprint ( $\left.\mathrm{LCEF}_{\text {total }}\right)$ of the building, as well as to assess its impact due to resource consumption (energy, water, building materials, manpower etc.) and waste assimilation over the lifecycle. For an academic building located in India taken as a case study, the $\mathrm{LCEF}_{\text {total }}$ is found to be 4397.03 gha and the $\mathrm{LCEF}_{\text {total }}$ per unit floor area is $0.60 \mathrm{gha} / \mathrm{m}^{2}$. The average annual Ecological Footprint $\left(\mathrm{EF}_{\text {avg }}\right)$ of the academic building is $73.28 \mathrm{gha} / \mathrm{yr}$ that is approximately 20 times more than the actual physical land of the campus. The average annual Ecological Footprint per student $\left(\mathrm{EF}_{\mathrm{avg} / \mathrm{student}}\right)$ of the academic building is 0.045 $\mathrm{gha} / \mathrm{yr} /$ student. If annual grid electricity consumption of the building is replaced by the grid-connected rooftop photovoltaic (GRSPV) system in the ratios of $100 \%, 75 \%, 50 \%$ and $25 \%$, it can reduce up to $61 \%$, $54 \%, 31 \%$, and $15 \%$ of the total $\mathrm{LCEF}_{\text {total }}$ of the academic building, respectively.
\end{abstract}

Keywords: ecological footprint, life cycle assessment, energy analysis, academic building, embodied emission

\section{INTRODUCTION}

The building sector is responsible for about $32 \%$ of the total energy consumption and $19 \%$ of energy related $\mathrm{CO}_{2}$ emissions globally (IPCC, 2014). Approximately $50 \%$ of the total energy is consumed for maintaining thermal comfort (heating/cooling) inside the built envelope during the operational phase of the building. The construction sector in India has been growing at the average annual rate of $10 \%$ over the last decade. The housing stock in India has increased at a remarkable rate, from 250 million units in the year 2001 to 330 million units in the year 2011 (ORG and CC, 2011). In India, energy demand for material manufacturing is nearly 20-25\% of the total energy demand while annual building material consumption is exceeding 2 billion tonnes. Simultaneously GHG emissions by construction sector are contributing up to 30\% of the total GHG emissions of the country (Mani et al., 2012).

For environmental protection regulation, waste assimilation is another challenging task after the GHG emissions. The annual waste generated in India is about 62 million tonnes while $25 \%$ of the total waste is contributed by construction and demolition $(C \& D)$ waste. $C \& D$ waste requires approximately 1240 hectare land per year. If the same growth rate in waste generation is maintained, it will reach 165 million tonnes by 2031, requiring as much as 66 thousand hectares of useful land for waste disposal in the next 20 years (considering $10 \mathrm{~m}$ 
high waste pile) [PCR, 2014]. Various studies acknowledged that majority of waste generated during the time of demolition phase of building can be recycled up to $25-40 \%$ and the rest is disposed of in landfill (TIFAC, 2017). Therefore, reuse or recycling of the $\mathrm{C} \& \mathrm{D}$ waste can help in saving energy, materials, and the environment.

LCA is a well-known technique for evaluation of ecological impact quantitatively. Varun et al. investigated that the life cycle energy and GHG emissions for a three storey institutional building are $6.67 \mathrm{GJ} / \mathrm{m}^{2}$ and 0.45 $\mathrm{tCO}_{2 \mathrm{eq}} / \mathrm{m}^{2}$, respectively (Varun et al., 2012). Ramesh et al. conducted a review of the life cycle energy (LCE) analysis of buildings (both residential \& commercial) and suggest that operational phase $(80-90 \%)$ contribute a significant role in total building's energy demand (Ramesh et al., 2010). Ramesh et al. (2012) reported that the LCE of residential buildings is around of $240-380 \mathrm{kWh} / \mathrm{m}^{2} /$ year, and the operational phase of the building consumes $80-90 \%$ of LCE in India. Pinky et al. (2014) investigated that building operational phase contributed $62-77 \%$ and construction phase contributed $22-36 \%$ of the total life cycle energy depending upon the building life. Azzouz et al. (2017) investigated that operational carbon and energy consumption of a building are 6.8 and 10.5 times higher than their embodied carbon and energy, respectively. During building maintenance, energy consumption and emissions are negligible as well as difficult to estimate, therefore ignore its value for building life cycle analysis (Ramesh et al., 2012; Zhang et al., 2016). LCA of building typically did not include impacts due to manpower/labour involved. Cole. (1998) found that labour transportation could account for $10-80 \%$ of total construction energy. The studies reported did not estimate the impact of resources like water consumption, manpower, waste assimilation, and built land etc. on the environment. These resources have significant impact on our earth and should not be neglected.

Ecological Footprint (EF): In the last three decades, various tools (such as Ecological Footprint (EF), life cycle energy and carbon assessment etc.) have been developed to estimate the sustainability of a system. The Ecological Footprint has emerged as one of the world's leading measures of human demand on nature. The EF concept was created in mid-nineties by Mathis Wackernagel and William Rees (Wackernagel and Rees, 1996). It can be used to examine various measures such as the feasibility of resource consumption, distribution of the world's natural resources, waste assimilation and overall sustainability of a system.

The Ecological Footprint of an activity is expressed in terms of global hectare (gha), which is defined, as "One global hectare is equivalent to one hectare of bio-productive land with world average productivity". The expression for evaluating EF (in gha) is as follows:

$$
\text { Ecological Footprint }(\mathrm{EF})=\sum\left(\mathrm{C}_{\mathrm{i}} / \mathrm{Y}_{\mathrm{i}}\right) \cdot \mathrm{e}_{\mathrm{i}}
$$

where, $\mathrm{C}_{\mathrm{i}}$ is annual consumption of item $\mathrm{i}(\mathrm{kg} / \mathrm{yr}), \mathrm{Y}_{\mathrm{i}}$ is annual productivity of item $\mathrm{i}(\mathrm{kg} / \mathrm{ha})$, Carbon sequestration due to human activities (such as fossil fuel burning, emission during material production, transportation etc.) can be expressed as follows:

$$
\text { EF of carbon sequestration }=\mathrm{P}_{c}\left\{\left(1-\mathrm{S}_{\mathrm{oc}}\right) / \mathrm{Y}_{\mathrm{c}}\right\} . \mathrm{e}_{\mathrm{i}}
$$

where, $P_{C}$ is annual $\mathrm{CO}_{2}$ emissions, $\mathrm{S}_{\mathrm{oc}}$ is the fraction of annual oceanic anthropogenic $\mathrm{CO}_{2}$ sequestration and $Y_{C}$ is the annual rate of carbon uptake/hectare of forestland at world average yield (GFN, 2010).

Conway et al. calculated the EF of the operational phase of the University of Toronto at Mississauga (UTM) based on energy, waste, and water, along with food and transportation. They found that energy contributed more than half the share in the EF of UTM (Conway et al., 2008). Solis Guzman et al. (2013) developed the methodology to find the EF for the construction phase of residential buildings in Spain and found that the EF of the built envelope was 0.384 gha/year per $\mathrm{m}^{2}$ floor area. Martínez Rocamora et al. (2017) found annual EF of an institutional building as $94.77 \mathrm{gha} / \mathrm{yr}$ with $92.7 \%$ share of carbon absorption. Gottlieb et al. (2012) calculated annual EF of a school as 314 gha that was 160 times larger than their physical or built-up land. Teng and Wu (2014) evaluated the eco-footprint and eco-efficiency in each phase of the life cycle of an institute building, but taking many assumptions such as building construction $\&$ demolition time, demolition energy factors etc. For building environmental impact assessment, it is necessary to perform a complete inventory analysis of resource and energy consumption, waste assimilation, recycling and the process of construction, and demolition.

This paper focuses on the ecological impact of a typical academic building in India. This study is significant, as huge enhancement in infrastructure will be needed in near future to improve current education scenario in India. According to GFN (2017a), the total Ecological Footprint and per capita Ecological Footprint of India are 1.36 billion gha and $1.1 \mathrm{gha} /$ person, respectively; while biocapacity deficit of the country is $0.7 \mathrm{gha} / \mathrm{person}$. Indian resource demands have already surpassed the available bio-capacity of the country. This study is a step in the overall estimation of natural resource demand of the Indian education sector. Such a study may also be helpful in exploring the possibilities of reducing EF of the education sector of the country. 


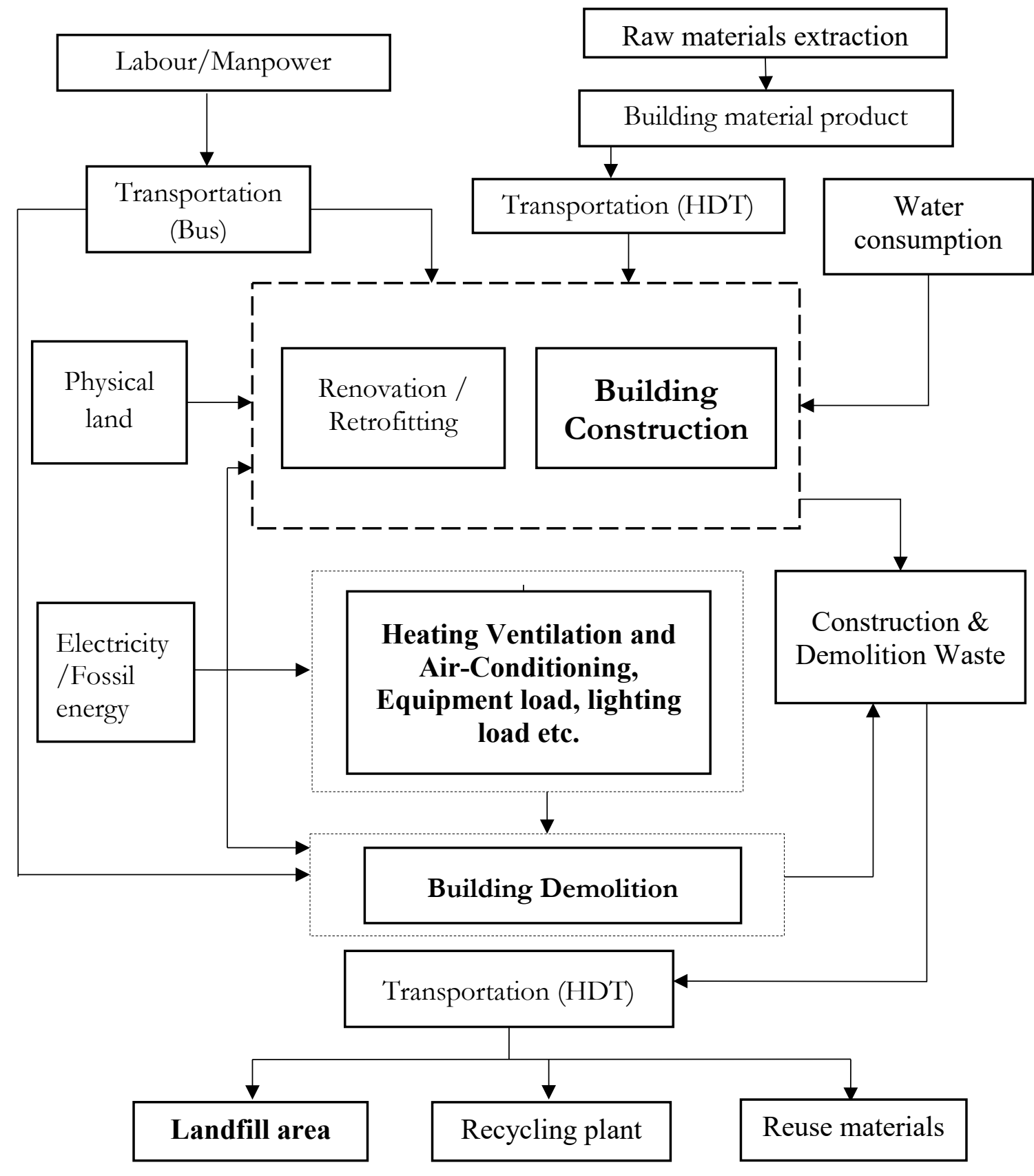

Figure 1. Life cycle analysis of building

\section{METHODOLOGY}

\section{Life Cycle Ecological Footprint of a Building Project $\left(\mathrm{LCEF}_{\text {total }}\right)$}

In this paper, the EF indicator has been integrated with the LCA approach for assessment of the impact of a building project on the biosphere that determines the $\mathrm{LCEF}_{\text {total }}$ of a building based on natural resource consumption, GHG emissions, and waste assimilation etc. LCA of building project is defined as to investigate and measure the ecological consequences during their life, from the extraction of raw materials, material production, construction phase, use \& maintenance phase, materials \& $C \& D$ waste transportation, and demolition phase. LCA system boundary of a building project based on cradle-to-grave approach is depicted in Figure 1.

It begins with the implementation of a building project and progresses with the construction, operation, maintenance, and ends with building demolition. The lifecycle of a building associated with resource consumption (fuel, electricity, material, water etc.), transportation, manpower, land use and waste generation, and its disposal or recycling. All above parameters convert into the equivalent productive land needed to produce or absorb their 


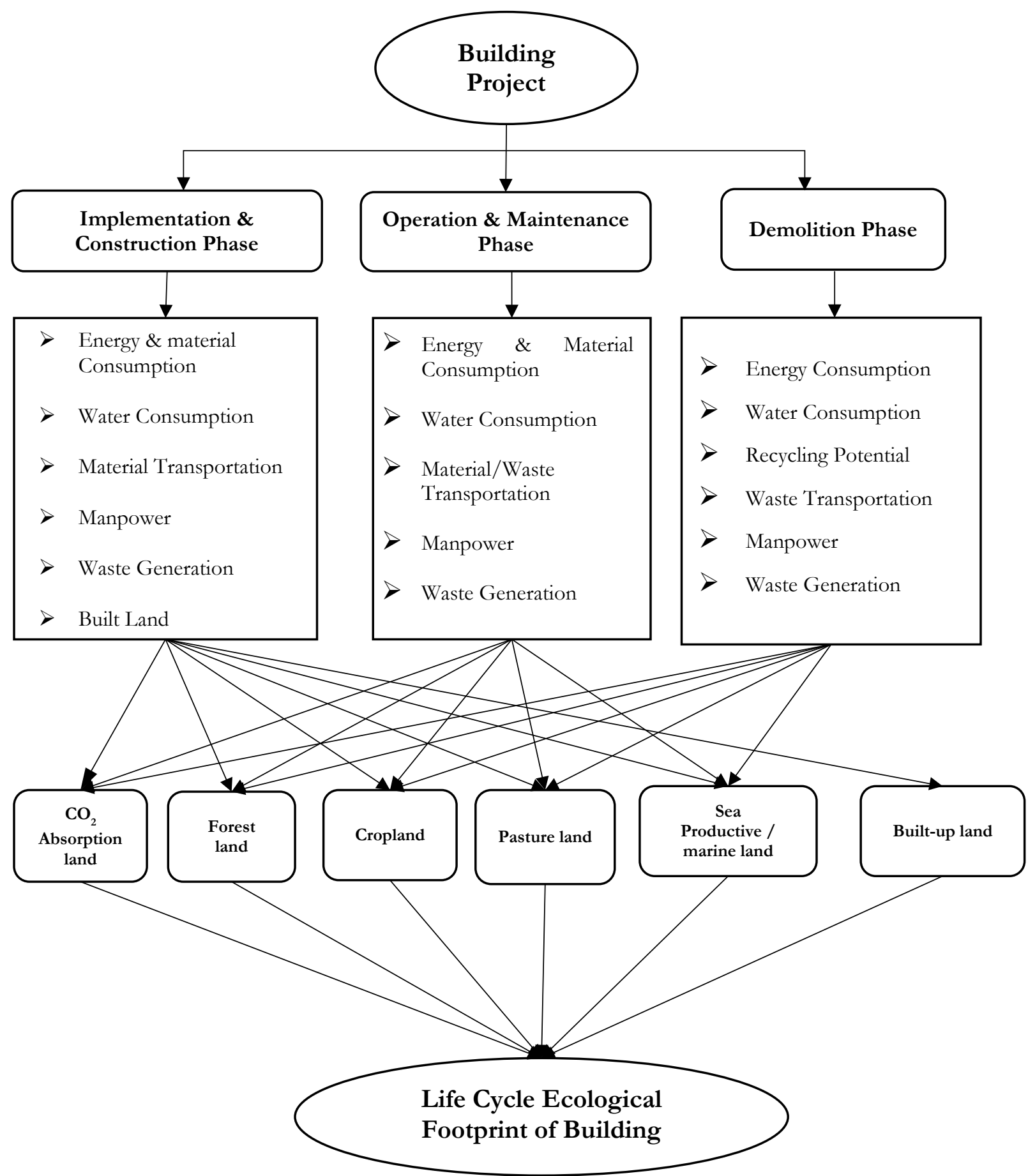

Figure 2. Methodology flow-chart for life cycle ecological footprint of building project

impacts in the form of $\mathrm{CO}_{2}$ absorption land, forestland, cropland, and built-up land. $\mathrm{LCEF}_{\text {total }}$ contains all phases of building's life: implementation \& construction phase, operation \& maintenance phase and demolition phase. The principle of evaluating the $\mathrm{LCEF}_{\text {total }}$ of a building is shown in Figure 2. It is used to effectively examine the impact of building project on the earth and calculated with Eq. (3):

$$
\mathrm{LCEF}_{\text {total }}=\mathrm{LCEF}_{\text {e\&m }}+\mathrm{LCEF}_{\mathrm{w}}+\mathrm{LCEF}_{\mathrm{t}}+\mathrm{LCEF}_{\mathrm{we}}+\mathrm{LCEF}_{\mathrm{m}}+\mathrm{LCEF}_{\text {built-up }}
$$

where, $\mathrm{LCEF}_{\mathrm{e} \& \mathrm{~m}}, \mathrm{LCEF}_{\mathrm{w}}, \mathrm{LCEF}_{\mathrm{t}}, \mathrm{LCEF}_{\mathrm{we}}, \mathrm{LCEF}_{\mathrm{m}}$ and $\mathrm{LCEF}_{\text {built-up }}$ represent the life cycle ecological footprint of energy and material consumption, water consumption, transportation, waste generation, manpower, and built-up land consumption of the building, respectively. 


\section{Life Cycle Ecological Footprint of Energy and Materials Consumption (LCEF e\&m)}

The $\mathrm{LCEF}_{\text {e\&m }}$ of a building is estimated by summing up the energy \& materials expenditure for each phase of the building life. The building's $\mathrm{LCEF}_{\mathrm{e} \& \mathrm{~m}}$ is calculated using following relations:

$$
\mathrm{LCEF}_{\mathrm{e} \& \mathrm{~m}}=\left\{L_{\mathrm{CO}_{2}} \cdot\left(\left(1-S_{o c}\right) / A f\right)\right\} \cdot e_{\mathrm{CO}_{2} \text { land }}+\left\{\sum \frac{\mathrm{C}_{\mathrm{wi}}}{\mathrm{Y}_{\mathrm{wi}}}\right\} \cdot e_{\text {forest }}
$$

where; $\mathrm{LCO}_{2}$ is total life cycle emission of a building, the total life cycle emission during the lifespan of a building due to direct energy used and embodied material energy (neglecting material and energy consumption during building maintenance) is calculated using following relations:

$$
L_{\mathrm{CO} 2}=M_{\mathrm{CO} 2}+\sum\left(E_{c} \cdot \lambda_{i}\right)+\left(E_{o} \cdot L_{b}\right) \cdot \lambda_{\text {electricity }}+\sum\left(E_{d} \cdot \lambda_{i}\right)
$$

where; $M_{\mathrm{CO} 2}=$ Embodied $\mathrm{CO}_{2}$ emission of building materials; $E_{c}=$ direct energy consumption in construction work (i.e. machinery used); $E_{o}=$ Annual operational electricity consumption of building; $E_{d}=$ direct energy consumption in demolition work (i.e. machinery used); $L_{b}=$ Building operation time (60 years); $\lambda_{i}$ corresponding emission factor of ith fuel and $\lambda_{\text {electricity }}$ is $0.82 \mathrm{tCO}_{2} / \mathrm{MWh}$ emission conversion factor of electricity generation in India (MPCEA, 2016).

Scripps Institution of Oceanography estimated that $30 \%$ of global carbon di oxide $\left(\mathrm{CO}_{2}\right)$ emissions from all emission sources in the earth over the period of 2002-2011 were absorbed by the oceans (SIO, 2017). Therefore, fraction of anthropogenic emissions sequestered by oceans $\left(\mathrm{S}_{\mathrm{oc}}\right)$ is 0.30 . The world average forest carbon sequestration (AFCS) rate is estimated to be $0.73 \pm 0.37 \mathrm{tC} . \mathrm{ha}^{-1}$ (Mancini et al., 2016). If converted AFCS data in to world average forest $\mathrm{CO}_{2}$ sequestration that is $2.68 \pm 1.36 \mathrm{tCO}_{2} \cdot \mathrm{ha}^{-1}\left(\mathrm{~A}_{\mathrm{f}}\right.$ absorption factor of forests is considered to be $2.68 \mathrm{tCO}_{2} / \mathrm{ha}$ ). $\mathrm{C}_{\mathrm{wi}}$ life cycle consumption of ith wooden material $\left(\mathrm{t}\right.$ or $\left.\mathrm{m}^{3}\right)$; $\mathrm{Y}_{\mathrm{wi}}$, is yield of wood production in India $\left(73 \mathrm{~m}^{3} / \mathrm{ha}\right.$ (FSI. 2015)), $e_{\text {forest land }} \& e_{\mathrm{CO}_{2} \text { land }}$ are equivalence factor of forestland (1.28gha/ha) and $\mathrm{CO}_{2}$ absorption land (1.28 gha/ha), respectively (GFN, 2017b).

\section{Life Cycle Ecological Footprint of Transportation (LCEFt)}

The LCEF $_{t}$ consists of three stages (a) raw material transportation from factory to construction site, (b) manpower transportation from their houses to project site, (c) C\&D waste disposal from the site to land fill area. Energy and resource consumed, and $\mathrm{CO}_{2}$ emitted by transportation during implementation are very low and nearly $1.1 \%$ of the construction of the building (Jiang, 2011; Li, 2012). To estimate the $\mathrm{LCEF}_{\mathrm{t}}$ of the building, neglect material and waste transportation during building maintenance.

Few assumptions are taken to determine the $\mathrm{LCEF}_{\mathrm{t}}$, which is given below:

1. The average distance from the factory to the construction site for materials is the range of $20-30 \mathrm{~km}$.

2. The average distance travelled by labours to reach the construction site is the range of $10-15 \mathrm{~km}$.

3. All materials and C\&D wastes (neglect maintenance waste) transported through HDT.

4. All workers travel by public transport systems (i.e. $86.12 \%$ of total passenger kilometres travelled by public transport in India that was estimated by (Reddy and Balachandra, 2010)) mainly buses.

The Life cycle EF of transportation is calculated with Eq. (6):

$$
\mathrm{LCEF}_{\mathrm{t}}=\left\{\left(\sum \frac{C_{m i} \cdot D_{m i}}{T_{c}}+\sum \frac{C_{w j} \cdot D_{w j}}{T_{c}}\right) \cdot E_{\mathrm{truck}}+\sum \frac{M_{k} \cdot D_{m k}}{T_{b}} \cdot E_{\mathrm{bus}}\right\} \cdot \lambda_{\text {diesel }} \cdot\left(\frac{1-\mathrm{S}_{o c}}{A f}\right) \cdot e_{C O_{2} l a n d}
$$

where, $C_{m i}$ and $D_{m i}$ are weight of transportable of $i$ th material and average distance of transportation of $i$ th material, respectively; $C_{w j}$ and $D_{w j}$ are waste and average distance of transportation of $j$ th material, respectively; $M_{k}$ and $D_{m k}$ are number of labour and average distance travelled by the labour. $T_{c}$ and $T_{b}$ represent the capacity of truck (3.5 ton) and bus (50 passenger), respectively; and $\lambda_{\text {diesel }}$ emission factor of diesel fuel $\left(3.17 \mathrm{CO}_{2} \mathrm{~kg} / \mathrm{kg}\right.$ of diesel (EEA, 2013)). The average fuel efficiency of HDT $\left(E_{\text {truck }}\right)$ and Bus $\left(E_{\text {bus }}\right)$ are 0.222 and $0.238 \mathrm{~kg}$ of fuel $/ \mathrm{km}$, respectively (Baidya and Borken-Kleefeld, 2009).

\section{Life Cycle Ecological Footprint of Manpower ( $\left.L C E F_{m}\right)$}

The $\mathrm{LCEF}_{\text {total }}$ associated with manpower impact is studied by focusing mostly on the food and mobility. The impact of manpower's mobility has already been considered in Section 2.1.2, therefore, only food consumption taking into account to assess the $\mathrm{LCEF}_{\mathrm{m}}$. Moreover, it could be assumed that food provides the energy needed to do the work. To determine the $\mathrm{LCEF}_{\mathrm{m}}$, food consumption taken by labourers during working hours is considered for impact on the environment of a building [34].

The food consumption should be assessed by considering all types of food such as vegetable and animal-based products separately. According to National sample survey office (NSSO, 2014) "Household Consumption of Various Goods and Services in India 2011-12", Ministry of Statistics and Programme Implementation, Government 
of India, June 2014 report. Due to lack of data of daily distribution of nutrients in the standard Indian diet, we assume that during work-hour (8 hrs) nearly 60\% (175 kcal/hr (Fitness blender, 2018) of the daily metabolic calories burned $(2400 \mathrm{kcal} /$ day (NIN, 2011)) by a construction labour. The total number of hours worked during construction \& demolition is obtained from the Central Public Works Department (CPWD, 2014).The LCEF $\mathrm{m}_{\mathrm{m}}$ is determined by Eq. (7).

$$
\mathrm{LCEF}_{m}=\frac{d_{w}}{365} \cdot f_{d}\left\{\sum\left(\frac{C_{f_{i}}}{Y_{f_{i}}}\right) \cdot e_{i}+\sum\left(C_{\mathrm{fuel}_{j}} \cdot \lambda_{j}\right) \cdot \frac{\left(1-S_{o c}\right)}{A_{f}} \cdot e_{C_{2} \text { land }}\right\}
$$

where, $d_{w}$ is total number of labour-days worked during building life; $f_{d}$ is daily food intake fraction of an Indian adult $(60 \%), C_{f_{i}}$ is food consumption category $j$ during building life $(\mathrm{kg} / \mathrm{person} / \mathrm{yr}) ; Y_{f_{i}}$ is food production yield of ith $(\mathrm{kg} / \mathrm{ha} / \mathrm{yr}) . C_{\text {fuel }_{j}}$ is fuel consumption category $j$ during building life ( $\mathrm{kg} /$ person $\left./ \mathrm{yr}\right), \lambda_{j}$ is emission factor of category $j$ fuel.

According to goods consumption in India (i.e. urban \& rural areas) (NSSO, 2014), annual EF of food consumption per capita in India is depicted in Appendix A. Bio-productive lands fraction involved in annual EF of food consumption (area wise) depicted in Appendix B.

\section{Life Cycle Ecological Footprint of Waste Disposal ( $\left.L C E F_{\text {we }}\right)$ :}

The building's waste generally results in transportation and landfill disposal of the materials while transportation is considered in transportation section. However, some waste material can be recycled that may reduce environmental impact. According to TERI, (2004), waste generation during building construction phase is 40 $\mathrm{kg} / \mathrm{m}^{2}$ to $60 \mathrm{~kg} / \mathrm{m}^{2}$, waste generation during building maintenance is range between $40 \mathrm{~kg} / \mathrm{m}^{2}$ to $50 \mathrm{~kg} / \mathrm{m}^{2}$. The highest share of waste generation during building life comes from the demolition phase. Demolition of pucca and semi-pucca buildings, on average generates between $300 \mathrm{~kg} / \mathrm{m}^{2}$ and $500 \mathrm{~kg} / \mathrm{m}^{2}$ of waste, respectively (TERI, 2004). Recovery rates vary from $25 \%$ in old buildings to as high as $75 \%$ in new buildings (WMW, 2017).

According to TERI (2004), volume of waste material generated during building demolition per floor area of Masonry and Concrete \& mortar is $0.3825 \mathrm{~m}^{3}$ and $0.5253 \mathrm{~m}^{3}$, respectively. The volume of waste materials is converted to mass in ton by material density (Masonry: $1600 \mathrm{~kg} / \mathrm{m}^{3}$, Concrete and mortar $1920 \mathrm{~kg} / \mathrm{m}^{3}$ ). For estimation of the Life cycle EF of waste disposal, the average height of waste dump is 10 feet $(3.3 \mathrm{~m})$ considered and assumed the life of the C\&D waste is about 75 years. The life cycle EF of waste is determined through Eq. (8).

$$
\mathrm{LCEF}_{\mathrm{we}}=\sum \frac{W_{d w_{i}}}{Y_{d w_{i}}} \cdot e_{\text {landfill }}
$$

where, $Y_{d w_{i}}$ \{(i.e. waste deposit capacity in one hectare bio-productive land)/(decomposition time of waste)\} represents the yield of C\&D waste disposal ( $\left.\mathrm{m}^{3} / \mathrm{ha}\right) ; W_{d w_{i}}$ represents the amount of waste $\left(\mathrm{m}^{3}\right)$, and $e_{\text {landfill }}(0.43$ gha/ha pasture land (GFN, 2017b)); represents the equivalence factor of the type of bio productive land for the waste to be disposed (gha/ha).

This study is focused only on waste generation during construction and demolition phases of a building. However, waste generated during maintenance phase is not considered in the analysis because of lack of data in Indian construction sector as well as negligible impact on the building lifecycle analysis. All C\&D waste disposed to the landfill, however, recycling and reuse of waste materials are not considered.

\section{Life Cycle Ecological Footprint of Water Consumption (LCEF $\left.F_{\mathrm{w}}\right)$ :}

The water consumption during the life cycle of a building largely remains undocumented in India. Water consumption mainly results in construction and operation phase while demolition phase does not consider it because of very less amount of water need. Bardhan (2011) analysed that water demand in material production, as well as construction phase, is about 27 Kilolitres $/ \mathrm{m}^{2}$ of the total built-up area for typical urban constructions in India. Water consumption in building maintenance $\&$ demolition is essential but due to lack of data, we neglected water consumption in these building phases. Ground water is generally used in building construction in India, therefore $\mathrm{CO}_{2}$ absorption land needed to compensate the electrical energy that is used for uplifting water from underground to certain height. The $\mathrm{LCEF}_{\mathrm{w}}$ is determined through Eq. (9).

$$
\mathrm{LCEF}_{\mathrm{w}}=C_{w} \cdot E_{w} \cdot \lambda_{i} \cdot \frac{\left(1-S_{o c}\right)}{A_{f}} \cdot e_{C O_{2} l a n d}
$$

where, $C_{w}$ is total water consumption during all phase of building life $\left(\mathrm{m}^{3}\right) ; E_{w}$ is the rate of energy consumption per litre to water extraction from ground; $\lambda_{i}$ is emission factor of $i$ th fuel (such as diesel, electricity etc.) that use to extract water. 


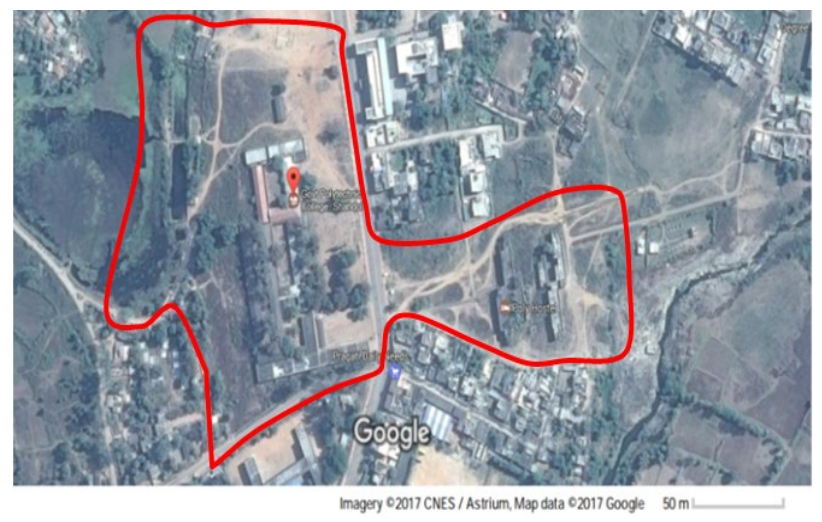

(a)

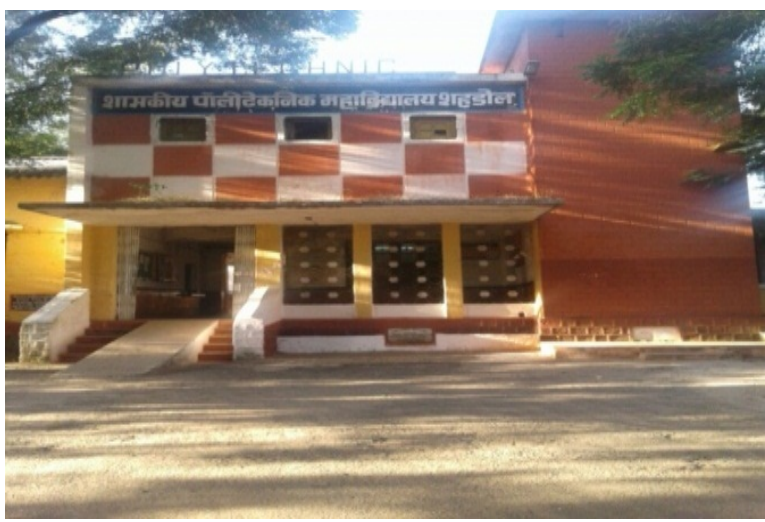

(b)

Figure 3. (a) Satellite image of institute campus; (b) Image of academic building

\section{Life Cycle Ecological Footprint of Built-up Land ( $\left.L C E F_{\text {built-up }}\right)$ :}

Building is involved with various bio-productive land categories: (1) $\mathrm{CO}_{2}$ land (2) forestland (3) cropland (4) pasture land \& (5) sea land etc. However, the direct physical land use for construction is discuss in this section. The $\mathrm{LCEF}_{\text {built-up }}$ is calculated by:

$$
\mathrm{LCEF}_{\text {built-up }}=A_{b} \cdot e_{\text {built-up land }}
$$

where, $\mathrm{LCEF}_{\text {built-up }}$ is the ecological footprint of direct land occupation (gha), $A_{b}$ is the total built-up land (ha) and $e_{\text {built-up land }}$ is the equivalence factor of built-up land (2.52 gha/ha(GFN, 2017b)).

\section{CASE STUDY}

\section{Building Description}

Life cycle ecological footprint of an academic building has calculated as a way to measure progress towards a broad goal of increasing the sustainability of education system. In this study, $\mathrm{LCEF}_{\text {total }}$ of the Government Polytechnic College, Shahdol campus building located in Madhya Pradesh, India. The campus building images are depicted in Figure 3(a, b). This institute is one of the campuses associated with the Rajiv Gandhi Prodoyogiki Vishwavidyalaya state university, Madhya Pradesh, India.

Area of campus is around 3.5 hectare, with college buildings ( $5857 \mathrm{~m}^{2}$ floor area), hostels (1462 $\mathrm{m}^{2}$ floor area), playground, and parking lots etc. In the academic year of 2015-2016, the institute was open for 236 days with scheduling of 9:00 am to 4:00 pm, there were 1440 full-time students and 40 office members (faculty \& staff) while approximately, 400 students lived in hostels. Electricity consumption data of academic buildings are taken from electricity bill paid (60821 kWh for six months) by college admiration.

\section{Average Annual Ecological Footprint of an Academic Building}

For calculation of average annual ecological footprint $\left(\mathrm{EF}_{\text {avg }}\right)$ of an academic building (the Government polytechnic college Shahdol), some assumption have been taken in to account: one year duration for building construction phase, 60 years duration of building operation phase, and one year duration of demolition and waste disposal phase. The Average annual ecological footprint $\left(\mathrm{EF}_{\mathrm{avg}}\right)$ of the building is calculated by given formula:

$$
\mathrm{EF}_{\mathrm{avg}}=\frac{\text { Life cycle ecological footprint of a building }\left(\mathrm{LCEF}_{\text {total }}\right)}{\text { Building life span }}
$$

The Average annual ecological footprint per floor area $\left(\mathrm{EF}_{\text {avg/floor area }}\right)$ of an academic building are given below:

$$
\mathrm{EF}_{\text {avg/floor area }}=\frac{\text { Life cycle Ecological Footprint of a building }}{\text { Building life span } \times \text { floor area of the building }}
$$

The Average annual ecological footprint per student $\left(\mathrm{EF}_{\text {avg/student }}\right)$ of an academic building are given below:

$$
\mathrm{EF}_{\mathrm{avg} / \mathrm{student}}=\frac{\text { Life cycle Ecological Footprint of a building }}{\text { Building life span } \times \text { No of student in one academic year }}
$$


Table 1. Material consumption in the academic building

\begin{tabular}{|c|c|c|c|c|}
\hline Materials & Unit & Consumption & Emission factor $\mathrm{kgCO}_{2} / \mathrm{kg}$ & EF(gha-yr) \\
\hline Burnt Clay Brick (1.84 kg each) & no & 1867320 & $0.162-0.195$ & 101 \\
\hline Cement & $\mathrm{kg}$ & 1613350 & $0.61-0.74$ & 103 \\
\hline Fine \& Coarse sand & $\mathrm{kg}$ & 2612770 & - & - \\
\hline Aggregates & $\mathrm{kg}$ & 257880 & 0.0048 & 1.96 \\
\hline Steel & $\mathrm{kg}$ & 1923500 & 1.74 & 973.3 \\
\hline Wood (Teak India) & $\mathrm{m}^{3}$ & 17.03 & - & 0.294 \\
\hline Glass (common) & $\mathrm{m}^{3}$ & 0.784 & 0.86 & 0.0015 \\
\hline Ceramic tile & $\mathrm{m}^{3}$ & 12.19 & 0.74 & 0.032 \\
\hline Marble stone & $\mathrm{m}^{3}$ & 1.8 & 0.116 & 0.0000065 \\
\hline PVC pipe & ton & 1.45 & 2.56 & 0.94 \\
\hline Paint & ton & 0.7 & $0.36 \mathrm{Kg} \mathrm{CO} 2 / \mathrm{m}^{2}$ & 0.064 \\
\hline
\end{tabular}

Table 2. Machinery used, Fuel consumption \& Emission factor

\begin{tabular}{lccccc}
\hline $\begin{array}{l}\text { Type of Input } \\
\text { energy }\end{array}$ & Capacity & Input energy & $\begin{array}{c}\text { Input energy } \\
\text { rate }\end{array}$ & $\begin{array}{c}\lambda(\mathbf{~ k g} \text { of CO } \\
\text { Total consumption }\end{array}$ & Total consumption \\
\hline Heavy duty truck & 3.5 ton & Diesel & $0.240 \mathrm{~kg} / \mathrm{km}$ & $3.17 \mathrm{CO}_{2} \mathrm{~kg} / \mathrm{kg}$ diesel & $15024.22 \mathrm{~kg}$ of diesel \\
\hline Bus & 50 passengers & Diesel & $0.238 \mathrm{~kg} / \mathrm{km}$ & $3.17 \mathrm{CO}_{2} \mathrm{~kg} / \mathrm{kg} \mathrm{diesel}$ & $986.75 \mathrm{~kg}$ of diesel \\
\hline Concrete mixer & $5 \mathrm{hp}$ & Diesel & $1.6 \mathrm{l} / \mathrm{hr}$ & $3.17 \mathrm{CO}_{2} \mathrm{~kg} / \mathrm{kg} \mathrm{diesel}$ & $161 \mathrm{~kg}$ of diesel \\
\hline Electrical vibrator & $1 \mathrm{hp}$ & Electricity & $0.745 \mathrm{kWh} / \mathrm{hr}$ & $0.82 \mathrm{tCO}_{2} / \mathrm{MWh}$ & $75.1 \mathrm{kWh}$ \\
\hline Water pump & $1 \mathrm{hp}$ & Electricity & $0.745 \mathrm{kWh} / \mathrm{hr}$ & $0.82 \mathrm{tCO}_{2} / \mathrm{MWh}$ & $14164 \mathrm{kWh}$ \\
\hline
\end{tabular}

Table 3. The LCEF $_{\text {total }}$ of the academic building

\begin{tabular}{|c|c|c|c|c|c|c|c|}
\hline \multicolumn{8}{|c|}{$\begin{array}{l}\text { Land type } \\
\end{array}$} \\
\hline & $\mathrm{CO}_{2}$ absorption & Forest land & Crop land & Pasture land & Sea-productive land & Built-up & Total (gha-yr) \\
\hline $\mathrm{LCEF}_{\mathrm{e} \& \mathrm{~m}}$ & 4339.56 & 0.30 & & & & & 4339.86 \\
\hline $\mathrm{LCEF}_{\mathrm{w}}$ & 9.66 & & & & & & 9.66 \\
\hline $\mathrm{LCEF}_{\mathrm{m}}$ & 1.51 & 0.03 & 10.34 & 2.12 & 0.82 & & 14.82 \\
\hline $\mathrm{LCEF}_{\mathrm{we}}$ & & & & 15.45 & & & 15.45 \\
\hline $\mathrm{LCEF}_{\mathrm{t}}$ & 8.75 & & & & & & 8.75 \\
\hline $\mathrm{LCEF}_{\text {built-up }}$ & & & & & & 8.49 & 8.49 \\
\hline Total LCEF & 4359.48 & 0.33 & 10.34 & 17.57 & 0.82 & 8.49 & \\
\hline Grand LCEF $_{\text {total }}$ & & & & & & & 4397.03 \\
\hline
\end{tabular}

\section{RESULTS \& DISCUSSONS}

\section{Life Cycle Ecological Footprint of the Building $\left(\operatorname{LCEF}_{\text {total }}\right)$}

In order to determine the $\mathrm{LCEF}_{\text {total }}$, all parameters $\left(\mathrm{LCEF}_{\mathrm{e} \& \mathrm{~m}}, \mathrm{LCEF}_{\mathrm{w}}, \mathrm{LCEF}_{\mathrm{m}}, \mathrm{LCEF}_{\mathrm{we}}, \& \mathrm{LCEF}_{\text {built-up land }}\right)$ are evaluated individually and then added to calculate total LCEF of the building. The detailed information about all parameters is shown in the Table 3 and percentage of different type of bio-productive land involved during the life cycle of the academic building is shown in Figure 5. The LCEF total of the academic building by using Eq. 3-10 is 4397.03 gha, and its maximum fraction is $\mathrm{CO}_{2}$ absorption land, which is about $99 \%$ of the total land impact. The $\mathrm{LCEF}_{\text {total }}$ per floor area is $0.6 \mathrm{gha} / \mathrm{m}^{2}$.

\section{Life Cycle Ecological Footprint of Energy and Materials Consumption (LCEF e\&m)}

The $\mathrm{LCEF}_{\text {e\&m }}$ of the building is estimated by summing up the EF of construction materials used, EF of construction energy, EF of building operational energy, and EF of demolition energy consumed during building life span. Due to lack of data and for simplicity, maintenance and materials recycling/reused impact are not considered in this section. Construction energy is calculated by using the data of machinery used for the construction site. Construction materials consumption and their EF have been obtained by using the data on Table 1 and it is calculated by using the Government of India report [CPWD, 2014]. Annual operational energy (electrical energy) is calculated by IES-VE ${ }^{\circledR}$ building simulation software because only 6-month electricity bills were available for the study. Table 2 data used for calculation of energy consumed during building construction.

The result of simulation for monthly electricity consumption of building is shown in Figure 4 . The monthly consumption value of simulation results have a maximum deviation of $9 \%$ with actual data for the month of August and total average deviation is around of $6 \%$, which is within acceptable limits. Therefore, we assume that the annual operation energy consumption obtained by simulation is in accordance with the actual energy consumption. The IES-VE simulation result shows that the total annual electricity consumption of the institutional building is (118.1 MWh) $16.14 \mathrm{kWh} / \mathrm{m}^{2}$ for the year of 2016. Due to lack of embodied $\mathrm{CO}_{2}$ emissions data of 


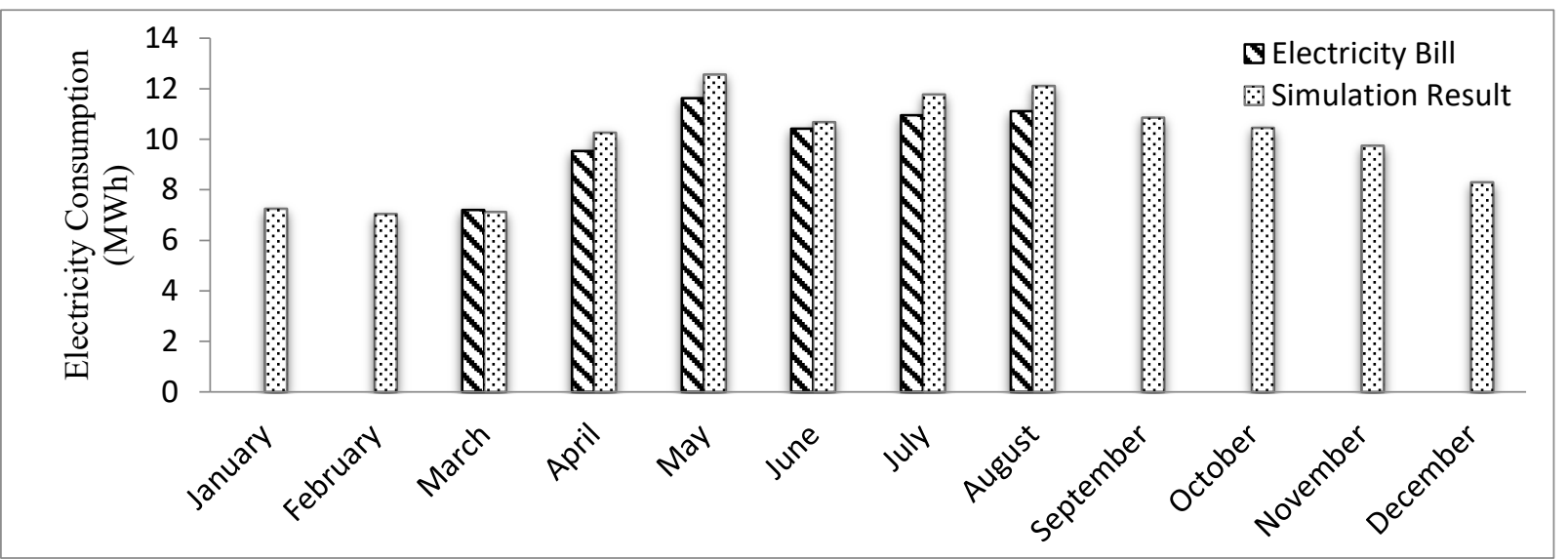

Figure 4. Simulation result of monthly electricity consumption of building

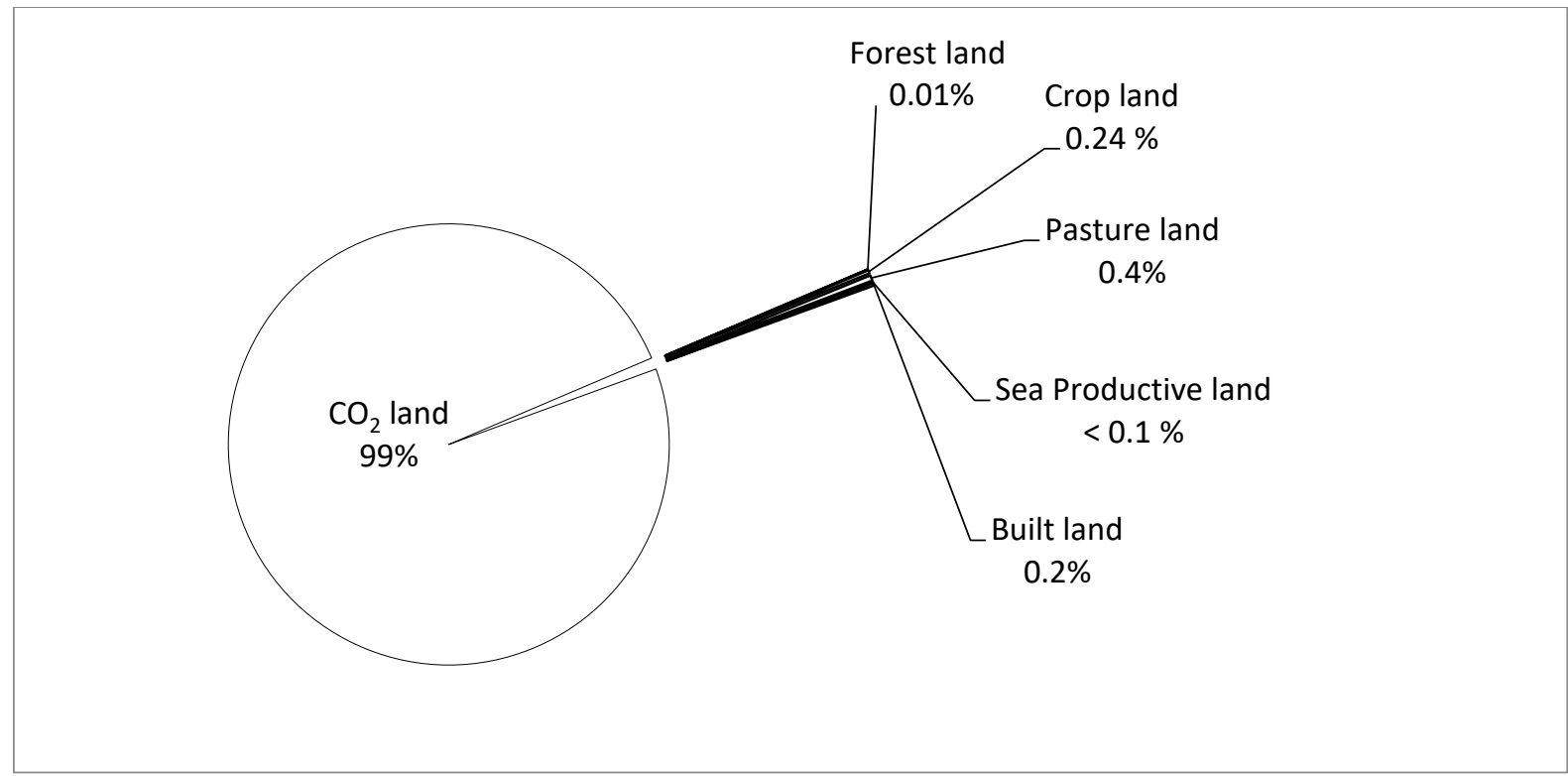

Figure 5. Percentage bio-productive land consume in the LCEFtotal of the building

building material for India, it is calculated using the emission data from Inventory of Carbon \& Energy (ICE, 2011), Sustainable Energy Research Team (SERT) report.

The $\mathrm{LCEF}_{\text {e\&m }}$ of the building calculated according to Section 2.1.1 is 4339.86 gha. The contribution of Ecological Footprint of the building's operational energy is approximately two third of the total LCEF $F_{\text {e\&m }}$, while second highest contributor is materials embodied energy of the building.

\section{Life Cycle Ecological Footprint of Transportation ( $\left.L C E F_{t}\right)$}

The location of a construction site is a major factor for the transportation of materials, workers, and

$\mathrm{C} \& \mathrm{D}$ waste during the life cycle of a building. This regional specificity should be a clear consideration of any building LCA, particularly focused in the construction and demolition phases. Fuel consumption during all type of transportation and their emission factors are shown in Table 2. The $\mathrm{LCEF}_{\mathrm{t}}$ of the building calculated according to Section 2.1.2 is 8.75 gha.

\section{Life Cycle Ecological Footprint of Manpower $\left(L C E F_{m}\right)$}

The LCEF $_{\mathrm{m}}$ was assessed through food consumption by the labourers during the working hours. The total number of labour-days is about 16458 during the life of the building, it is calculated by CPWD, Government of India 2014 report. The monthly goods consumption per person in urban India is obtained, by using the NSSO, (2014) report. The $\mathrm{LCEF}_{\mathrm{m}}$ of the building calculated according to Section 2.1.3 is 14.82 gha. This result indicates that for food consumption of Indian labourers, cropland dominantly contributes (typically more than $2 / 3$ of the total land) to the $\mathrm{LCEF}_{\mathrm{m}}$ of the building. 


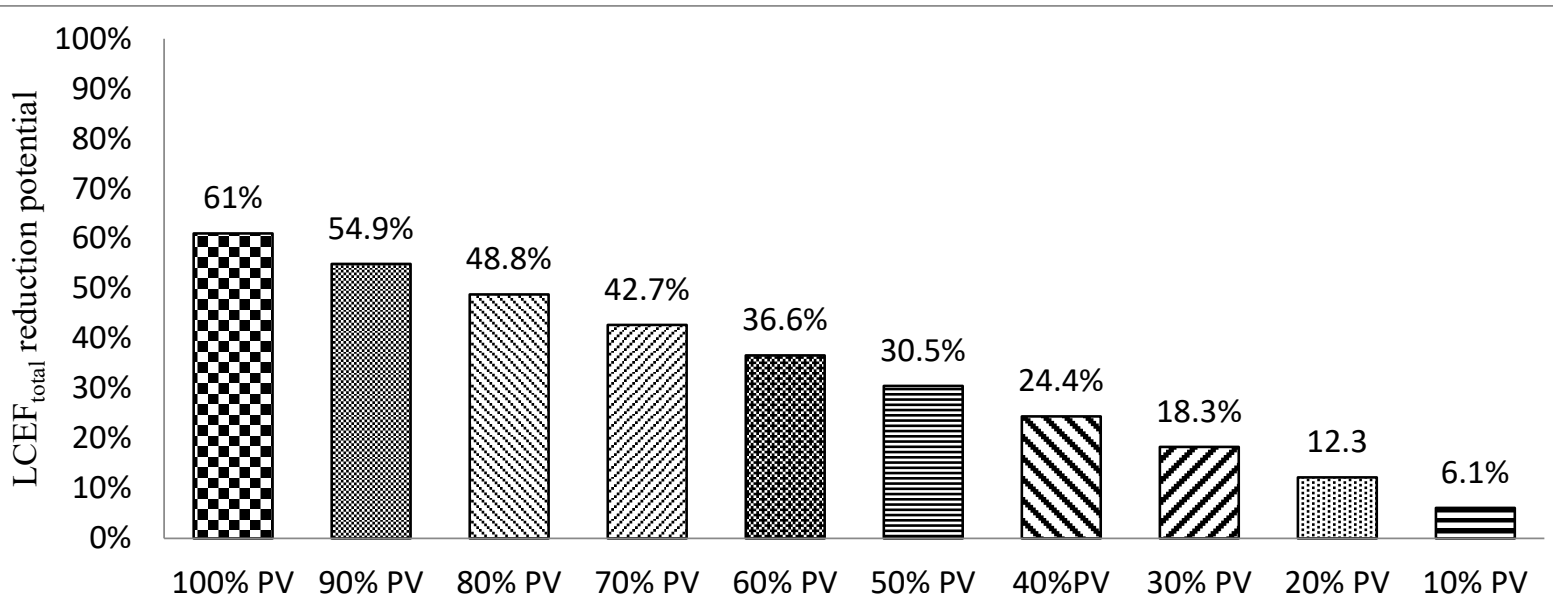

Figure 6. Percentage reduction of the $\mathrm{LCEF}_{\text {total }}$ through grid-connected PV system

\section{Life Cycle Ecological Footprint of Waste Disposal ( $\left.L C E F_{\text {we }}\right)$ :}

The generation of $C \& D$ waste during building life are determined through using real data of built-up area and building type, the amount of $C \& D$ waste is about $1581 \mathrm{~m}^{3}$ (approximately 2561.6 ton). The $\mathrm{LCEF}_{\mathrm{we}}$ of the building calculated according to Section 2.1.4 is 15.45 gha.

\section{Life Cycle Ecological Footprint of Water Consumption ( $L C E F_{\mathrm{w}}$ )}

For $\mathrm{LCEF}_{\mathrm{w}}$ estimation, $\mathrm{CO}_{2}$ absorption land was taken in to account. The water is mostly consumed during the construction phase of the building and it is calculated using data of building per floor area basis (Bardhan, 2011), the result of water consumption during construction is $197613 \mathrm{~m}^{3}$ of water. Due to lack of data and very low consumption, we are neglecting water consumption in demolition phase and maintenance phase of the building. The $\mathrm{LCEF}_{\mathrm{w}}$ of the building calculated by Eq. 7 is 9.66 gha.

\section{Life Cycle Ecological Footprint of Built-up Land ( $L C E F_{\text {built-up }}$ )}

The total land expended must be considered that are used for academic building and hostels building blocks (i.e. total campus area). The LCEF built-up of the building calculated by using Eq. (8) is 8.49 gha.

\section{Average Annual Ecological Footprint $\left(\mathrm{EF}_{\mathrm{avg}}\right)$ of the Building:}

The $\mathrm{EF}_{\text {avg }}$ of the academic building by using Eq. 9 is $73.28 \mathrm{gha} / \mathrm{yr}$. The $\mathrm{EF}_{\text {avg }}$ of the building required nearly 20 times more than the actual land (3.5 ha) of the institute campus.

\section{Average Annual Ecological Footprint per Unit Floor Area $\left(\mathrm{EF}_{\mathrm{avg} / \mathrm{floor} \text { area }}\right)$ of the Building:}

Eq. (10) is used to calculate the average annual ecological footprint of the academic building with respect to construction area $\left(7319 \mathrm{~m}^{2}\right)$ of the campus, which is $0.01 \mathrm{gha} / \mathrm{yr} / \mathrm{m}^{2}$.

\section{Average Annual Ecological Footprint per Student $\left(\mathrm{EF}_{\mathrm{avg}} / \mathrm{student}\right)$ of the Building:}

Eq. (11) is used to calculate the $\mathrm{EF}_{\text {avg/student }}$ of the academic building, which was $0.045 \mathrm{gha} / \mathrm{yr} / \mathrm{student}$ for the academic year of 2016.

\section{LCEF Reduction}

Various research studies on LCA of different types of solar photovoltaic (SPV) module systems suggest its potential to reduce environmental impact (Prakash and Bansal, 1995; Wild-Scholten, 2009; Keoleian and Lewis, 1997; Ito et al., 2008; Baharwani et al., 2014; Pacca et al., 2007; Cucchiella et al., 2015). Generally, mono crystalline SPV modules are used as rooftop SPV systems in India because its efficiency is high as compared to other types of SPV modules. Embodied energy of mono crystalline Silicon (mono-Si) SPV module is in the range of 2860 $3860 \mathrm{MJ} / \mathrm{m}^{2}$ (Wild-Scholten, 2009; Jungbluth et al., 2010; Laleman, 2011). Embodied energy of inverter (per kW $\mathrm{p}$ capacity) is around $503 \mathrm{MJ} / \mathrm{m}^{2}$ and that of installation (per $\mathrm{m}^{2}$ solar module) is about $34 \mathrm{MJ} / \mathrm{m}^{2}$ (Pacca et al., 2007). RETScreen ${ }^{\circledR}$ software was used for estimation of grid-connected rooftop solar photovoltaic (GRSPV) system capacity (20 years lifespan) to fulfil the annual electricity requirement of the building.

The potential reduction of the $\mathrm{LCEF}_{\text {total }}$ of the academic building due to the installation of GRSPV systems is depicted in Figure 6. If grid-electricity consumption is replaced by $100 \%, 75 \%, 50 \%$, and $25 \%$ through the GRSPV 
system, it can reduce up to $61 \%, 54 \%, 31 \%$, and $15 \%$ of the $\mathrm{LCEF}_{\text {total }}$ of the building, respectively. GRSPV system has reduction potential of $\mathrm{LCEF}_{\text {total }}$ of the academic building in range of 1698-1728 gha, if annual grid-electricity is completely replaced by GRSPV system i.e. the case of net zero energy building.

\section{CONCLUSIONS}

This case study assesses the ecological impact of an institutional building in India during its life span. It is intended to support building sustainability by conveying a practical method to assess life cycle ecological footprint as a sustainability indicator. By investigating the $\mathrm{LCEF}_{\text {total }}$ of a building using the component approach, the building can compared and differentiated based on their Ecological Footprint.

The $\mathrm{LCEF}_{\text {total }}$ of the academic building clearly indicates that the $\mathrm{CO}_{2}$ absorption land $\left(99 \%\right.$ of the $\left.\mathrm{LCEF}_{\text {total }}\right)$ is the most significant land in all consumed land types of the building. With this assessment, the effects of energy and materials consumption during the building life is highly significant and have the largest share in the LCEF total (i.e. around $98 \%$ ) of the building. For this type of activity, transportation, water, manpower, and waste assimilation carry very low decisive impacts as shown through this study.

From the awareness perception, the $\mathrm{LCEF}_{\text {total }}$ of the building result is presented as a single unit of land area. Therefore, any amateur person who has little knowledge about environment sustainability can easily understand it. The $\mathrm{EF}_{\text {avg }}$ of the academic building is $73.28 \mathrm{gha} / \mathrm{yr}$, and it required nearly 20 times more than the actual land of the campus. Martínez-Rocamora et al. (2017) also reported annual operational EF (including use, cleaning, maintenance) is about $94.772 \mathrm{gha} / \mathrm{yr}$ of a Hernando Colón Hall of Residence building. From Figure 6, maximum possible reduction in $\mathrm{LCEF}_{\text {total }}$ of the academic building is about $61 \%$ during building lifespan, if annual gridelectricity is completely replaced by GRSPV system.

The results obtained from such a study may be helpful in proposing and evaluating strategies for reduction in Ecological Footprint of institutional buildings. For example, in the domain of energy and materials, an institutional building might have to adopt green building technologies (e.g., solar cooling/heating systems, lime calcined clay cement $\left(\mathrm{LC}^{3}\right)$, insulation etc.) for significantly reducing the $\mathrm{CO}_{2}$ absorption land and thereby reducing the life cycle ecological footprint of the building.

\section{REFERENCES}

Azzouz, A., Borchers, M., Moreira, J. and Mavrogianni, A. (2017). Life cycle assessment of energy conservation measures during early stage office building design: A case study in London, UK. Energy and Buildings, 139, 547568. https://doi.org/10.1016/j.enbuild.2016.12.089

Baharwani, V., Meena, N., Dubey, A., Brighu U. and Mathur, J. (2014). Life Cycle Analysis of Solar PV System: A Review. International Journal of Environmental Research and Development, 4(2), 183-190. http://www.ripublication.com/ijerd.htm

Baidya, S. and Borken-Kleefeld, J. (2009). Atmospheric emissions from road transportation in India. Energy Policy, 37, 3812-3822. https://doi.org/10.1016/j.enpol.2009.07.010

Bardhan, S. (2011). Assessment of water resource consumption in building construction in India. WIT Transactions on Ecology and the Environment, 144, WIT Press. https://doi.org/10.2495/ECO110081

Central Public Works Department, Government of India. (2014). Analysis of Rates for Delhi (Volume-1\&2). Available at: http://cpwd.gov.in/Publication/DAR14-Vol1.pdf; http://cpwd.gov.in/Publication/DAR14Vol2.pdf (Accessed 17 August 2017)

Cole, R. (1998). Energy and greenhouse gas emissions associated with the construction of alternative structural systems. Building and Environment, 34(3), 335-348. https://doi.org/10.1016/S0360-1323(98)00020-1

Conway, T. M., Chelsea, D., Jennifer, L. and Laura, B. (2008). Developing ecological footprint scenarios on university campuses. International Journal of Sustainability in Higher Education, 9(1), 4-20. https://doi.org/10.1108/14676370810842157

Cucchiella, F., D'Adamo, I. and Koh, S.C.L. (2015). Environmental and economic analysis of building integrated photovoltaic systems in Italian regions. Journal of Cleaner Production, 98, 241-252. https://doi.org/10.1016/j.jclepro.2013.10.043

European Environment Agency. (2013). EMEP/EEA air pollutant emission inventory guidebook- 2013. Available at: http://www.eea.europa.eu/publications/emep-eea-guidebook-2013

Fitness blender. (2018). Available at: https://www.fitnessblender.com/articles/calories-burned-by-occupationhow-many-calories-does-my-job-burn (Accessed 3 March, 2018)

Forest Survey of India (FSI) (2015). Ministry of environment, forest \& climate change, report 2015. Available at: http://fsi.nic.in/details.php?pgID=sb_62 (Accessed 27 November 2017) 
Global Footprint Network. (2010). Calculation methodology for the national footprint accounts, 2010 edition. Available http://www.footprintnetwork.org/content/images/uploads/National_Footprint_Accounts_Method_Paper_ 2010.pdf (Accessed 21 August 2017)

Global Footprint Network (GFN). (2017a). Ecological Wealth of Nations. Available at: http://www.footprintnetwork.org/content/documents/ecological_footprint_nations/ecological.html

(Accessed December 2017)

Global Footprint Network (GFN). (2017b). Working Guidebook to the National Footprint Accounts. Available at: http://data.footprintnetwork.org/ (Accessed 09 December 2017)

Gottlieb, D., Kissinger, M., Vigoda-Gadot, E. and Haim, A. (2012). Analyzing the ecological footprint at the institutional scale - The case of an Israeli high-school. Ecological Indicators, 18, 91-97. https://doi.org/10.1016/j.ecolind.2011.10.010

International Panel on Climate Change (IPCC). (2014). Climate change 2014: Mitigation of Climate Change, contribution of working group III to the fifth assessment report of the Intergovernmental Panel on Climate Change. Cambridge University Press, Cambridge, United Kingdom. Available at: http://www.ipcc.ch/report/ar5/wg3/

Inventory of Carbon \& Energy (ICE). Sustainable Energy Research Team. (2011). Available at: www.bath.ac.uk/mech-eng/sert/embodied (Accessed 27 October 2017)

Ito, M., Kato, K., Komoto, K., Kichimi, T. and Kurokava, K. (2008). A comparative study on cost and life-cycle analysis for $100 \mathrm{MW}$ very large-scale (VLS-PV) systems in deserts using $\mathrm{m}-\mathrm{Si}$, a-Si CdTe and CIS modules. Progress in Photovoltaics Research and Application, 16, 17-30. https://doi.org/10.1002/pip.770

Jiang, X. X. Assessment of Low-Carbonized Construction of Residential Buildings in Towns and Villages. Huazhong University of Science and Technology (in Chinese).

Jungbluth, N., Stucki, M., Frischknecht, R. and Buesser, S. (2010). Photovoltaics. In Dones, R. (Ed.) et al., Sacbbilanzen von Energiesystemen: Grundlagen für den ökologischen Vergleich von Energiesystemen und den Einberug von Energiesystemen in Ökobilanzen für die Schweiz. ecoinvent report No. 6-XII, ESU-services Ltd, Uster, CH, 2010. file:///C:/Users/admin/Downloads/06_XII_Photovoltaic-v2.2plus\%20(2).pdf

Keoleian, G. A. and Lewis, G. M. (1997). Application of life-cycle energy analysis to photovoltaic module design. Progress in Photovoltaics Research and Applications, 5, 287-300. https://doi.org/10.1002/(SICI)1099159X(199707/08)5:4<287::AID-PIP169>3.0.CO;2-S

Laleman, R., Albrecht, J. and Dewulf, J. (2011). Life cycle analysis to estimate the environmental impact of residential photovoltaic systems in regions with a low solar irradiation. Renewable and Sustainable Energy Reviews, 15, 267-281. https://doi.org/10.1016/j.rser.2010.09.025

Li, B. (2012). Low-Carbon Building Technology System and Methods of Calculating Carbon Emission. Huazhong University of Science and Technology (in Chinese).

Mancini, M. S., Galli, A., Niccolucci, V., Lin, D., Bastianoni, S., Wackernagel, M. and Marchettini, N. (2016). Ecological Footprint: Refining the carbon Footprint calculation. Ecological Indicators, 61(2), 390-403. https://doi.org/10.1016/j.ecolind.2015.09.040

Mani, M. and Reddy, B. V. V. (2012). Sustainability in human settlements: imminent material and energy challenges for buildings in India. Journal of the Indian Institute of Science, 92, 145-162.

Martínez Rocamora, A., Solís-Guzmán, J. and Marrero, M. (2017). Ecological footprint of the use and maintenance phase of buildings: Maintenance tasks and final results. Energy and Buildings, 155, 339-351. https://doi.org/10.1016/j.enbuild.2017.09.038

Ministry of Power Central Electricity Authority (MPCEA), Government of India. (2016). CO2 Baseline Database for the Indian Power Sector, User Guide, 2016. Available at: http://www.cea.nic.in/reports/others/thermal/tpece/cdm_co2/user_guide_ver11.pdf (Accessed December 2016)

National Institute of Nutrition (NIN). (2011). Dietary Guidelines for Indians- A Manual. Available at: http:// ninindia.org/DietaryGuidelinesforNINwebsite.pd (Accessed 3 March 2018)

National Sample Survey Office (NSSO). (2014). Household Consumption of Various Goods and Services in India 2011-12. Ministry of Statistics and Programme Implementation, Government of India. Available at: http://mospi.nic.in/sites/default/files/publication_reports/Report_no558_rou68_30june14.pdf (Accessed 22 November 2017)

Office of the Registrar General \& Census Commissioner (ORG\&CC). (2011). India Ministry of Home Affairs, Government of India. Available at: http://censusindia.gov.in/2011 census/hlo/hlo_highlights.html (Accessed 31 August 2017)

Pacca, S., Sivaraman, D. and Keoleian, G. A. (2007). Parameters affecting the life cycle performance of PV technologies and systems. Energy Policy, 35, 3316-3326. https://doi.org/10.1016/j.enpol.2006.10.003 
Pinky, D., L. and Palaniappan, S. (2014). A case study on life cycle energy use of residential building in Southern India. Energy and Buildings, 80, 247-259. https:// doi.org/10.1016/j.enbuild.2014.05.034

Planning Commission Report (PCR), Government of India. (2014). Report of task force on waste to energy (volume I).

Prakash, R. and Bansal, N. K. (1995). Energy analysis of solar photovoltaic module production in India. Energy Sources, 17, 605-613. https://doi.org/10.1080/00908319508946107

Ramesh, T., Prakash, R. and Shukla, K.K. (2010). Life cycle analysis of buildings: An overview. Energy and Buildings, 42(10), 1592-1600. https://doi.org/10.1016/j.enbuild.2010.05.007

Ramesh, T., Prakash, R. and Shukla, K. K. (2012). Life cycle approach in evaluating energy performance of residential buildings in Indian context. Energy and Buildings, 54, 259-265. https://doi.org/10.1016/j.enbuild.2012.07.016

Reddy, S. and Balachandra, P. (2010). Dynamics of Urban Mobility: A Comparative Analysis of Megacities of India. Indira Gandhi Institute of Development Research, Mumbai. Available at: http:/ / www.eaber.org/system/tdf/documents/IGIDR_Reddy_1_2010.pdf?file=1\&type=node\&id=23122\& force

Scripps Institution of Oceanography (SIO). (2017). The Keeling Curve. Available at: https:/ / scripps.ucsd.edu/programs/keelingcurve/2013/07/03/how-much-co2-can-the-oceans-take-up/ (Accessed 13 March 2107)

Solís-Guzmán, J., Marrero, M. and Ramírez-de-Arellano, A. (2013). Methodology for determining the ecological footprint of the construction of residential buildings in Andalusia (Spain). Ecological. Indicators, 25, 239-249. https://doi.org/10. 1016/j.ecolind.2012.10.008

Technology Information, Forecasting \& Assessment Council (TIFAC). (2017). Department of science and technology, Government of India. Available http:/ / tifac.org.in/index.php?option=com_content\&view=article\&id=27\&Itemid=39 (Accessed 15 January 2017)

The Energy and Resources Institute (TERI). (2004). Sustainable Building Design Manual. Volume-2, New Delhi, TERI Press. ISBN: 9788179930533

Varun, S. A., Shree, V. and Nautiyal, H. (2012). Life cycle environmental assessment of an educational building in Northern India: A case study. Sustainable Cities and Society, 4, 22-28. https:// doi.org/10.1016/j.scs.2012.03.002

Wackernagel, M. and Rees, W. (1996). Our Ecological Footprint: Reducing Human Impact on the Earth. New Society, Gabriola Island, British Columbia

Waste Management World. (2017). Available at: http://www.waste-managementworld.com/articles/print/volume-12/issue-5/features/rebuilding-c-d-waste-recycling-efforts-in-india.html (Accessed 11 November 2017)

Wild-Scholten, M. (2009). Energy payback times of PV modules and systems. Energy Research Centre of the Netherlands. Workshop-Photovoltaik-Modultechnik, Koln, 26-27. Available at: http://www.solaik.ch/_downloads/EnergyPaybackTime.pdf

Zhang, Y., Zheng, X., Zhang, H., Chen, G. and Wang, X. (2016). Carbon emission analysis of a residential building in China through life cycle assessment. Frontiers of Environmental Science \& Engineering, 10(1), 150-158. https://doi.org/10.1007/s11783-014-0684-7 


\section{APPENDIX A}

Table 1A. Main household goods consumption per capita in India

\begin{tabular}{lcccc}
\hline Goods items & $\begin{array}{c}\text { Monthly rural } \\
\text { consumption (kg) } \\
\text { (NSSO, 2014) }\end{array}$ & $\begin{array}{c}\text { Monthly urban } \\
\text { consumption (kg) } \\
\text { (NSSO, 2014) }\end{array}$ & $\begin{array}{c}\text { Annual Urban EF } \\
\text { (gha) }\end{array}$ & Annual Rural EF ( gha ) \\
\hline Cereals & 11.22 & 9.28 & 0.117123 & 0.141608 \\
\hline Vegetable & 7.8 & 8.4 & 0.15748 & 0.146232 \\
\hline Pulses & 0.783 & 0.901 & 0.03926 & 0.034118 \\
\hline Oil & 0.674 & 0.853 & 0.06824 & 0.05392 \\
\hline Beef (meat) & 0.042 & 0.064 & 0.01032 & 0.006773 \\
\hline Goat (meat) & 0.049 & 0.079 & 0.005662 & 0.003512 \\
\hline Fish (meat) & 0.266 & 0.252 & 0.03024 & 0.03192 \\
\hline Fruits & 0.372 & 0.645 & 0.00000158 & 0.0506999 \\
\hline Milk & 4.5 & 5.54 & 0.062416 & 0.005342 \\
\hline Wood (material) & 19.04 & 4.3 & 0.001206 & 0.118282 \\
\hline Wood (fuel) & 19.04 & 4.3 & 0.026713 & 0.005012 \\
\hline LPG & 0.38 & 1.9 & 0.025059 & 0.005445 \\
\hline Kerosene & 0.53 (litre) & $0.4($ litre) & 0.00411 & $\mathbf{0 . 6 0 2 8 6 2}$ \\
\hline Total annual EF & & $\mathbf{0 . 6 5 4 9 0}$ & \\
\hline
\end{tabular}

\section{APPENDIX B}

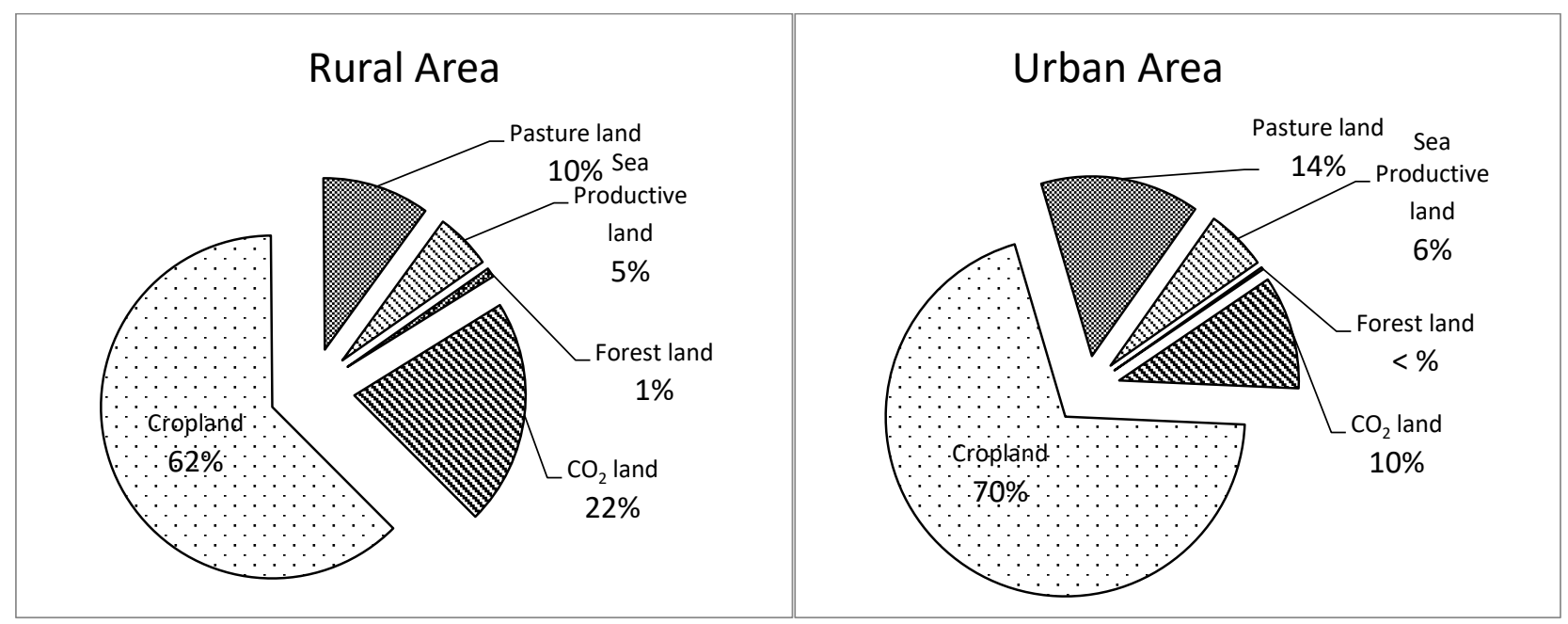

Figure 1A. Bio-productive land used due to food consumption per capita in India (rural \& urban area) 